\title{
Study on Zooplankton Diversity in A Fresh Water Pond (Raja Bandh) of Jamtara, Jharkhand, India
}

\author{
Seema Singh ${ }^{1}$, Veena Kumari ${ }^{1}$, Monalisa ${ }^{1}$, Basant Kumar Gupta ${ }^{1}$ and Mohommad Arif $^{2}$ \\ ${ }^{1}$ Deoghar College, Deoghar under Sido Kanhu Murmu University, Jharkhand 814112, India. \\ ${ }^{2}$ Defence Institute of Bio-Energy Research (DIBER), HQ, Haldwani, Uttarakhand- 263139, India. \\ ${ }^{\star}$ Correspondence E-mail : seemasinghania96@gmail.com
}

\begin{abstract}
Zooplankton are cosmopolitan in nature and one of the most important ecological parameter in water quality assessment because they help in disposal of sewage and act as natural purifiers of water. Present study was carried out for a period of one-year from July 2018 to June 2019. The present study deals with Zooplankton diversity throughout the year in raja Bandh Pond of Jamtara, Jharkhand. The diversity of various types of zooplankton was studied and the result revealed that the zooplankton was represented by various genera viz., rotifera, cladocera, copepoda and ostracoda. Present study revealed 14 different species of zooplanktons belonging to 4 different classes namely 5 rotifers, 4 cladocerans, 3 copepods and 2 ostracod was observed. Rotifers were the dominant group of Zooplankton recorded with respect to diversity and population density status. Rotifers and Copepoda were the most dominant during summer than followed by Cladocerans and ostracodes. Present study revealed that the annual percentage composition comprises of $38 \%$ rotifer, $26 \%$ copepod, $20 \%$, cladocera and $16 \%$ ostracoda respectively. Certain species viz, Brachionus sp, Daphnia sp, Cyclops $s p$, Cypris $s p$ were recorded throughout the year.
\end{abstract}

Keywords: Zooplankton; Raja Bandh; Rotifera; Cladocera; Copepoda;Ostracod.

\section{Introduction}

Zooplankton are a diverse group of heterotrophic organisms that consume phytoplankton, regenerate nutrients via their metabolism, and transfer energy to higher trophic levels (Steinberg and Robert, 2009). Zooplankton are central components of aquatic food webs and contribute suggestively to aquatic productivity in freshwater ecosystems. Zooplankton is microscopic organisms which do not have the ability of locomotion but move at the compassion of the water movements and wind. They occupy transitional position in the food web. Zooplankton mediate the transfer of energy from lower to higher tropic level thus zooplankton represent an important link in aquatic food chain and contribute significantly to secondary production in fresh water ecosystem (Sharma, 1998). It plays an important role in recycling nutrients as well as cycling energy within their respective environment. These are the main sources of natural food for fish which is directly related to their survival and growth and are base of food chains and food webs in all aquatic ecosystem (Miah et.al., 2013). They are the essential food item for fish larvae culture (Alam et.al., 1987). Zooplankton is a decent indicator of variations 
in water quality because it is strongly affected by environmental conditions. It responds quickly to changes in physical and chemical conditions as well as environmental conditions. Zooplankton communities respond to a wide variety of disturbances including nutrient loading, acidification and sediment input etc. The distribution and diversity of zooplanktons in aquatic ecosystems depend mainly on the physicochemical parameters of water (Saba and Sadhu, 2015). It is a wellsuited tool for understanding water pollution status (Contreras et al., 2009). Rotifers, Cladocerans, copepods and ostracods constitute the major groups of zooplankton (Kar and Kar, 2016).

Methodical studies on the Indian zooplankton began more than a century ago (Edmondson, 1959; Battish, 1992). Extensive regional surveys on faunal variability and diversity of zooplankton in freshwater environment are still deficient. Some workers has been done study on zooplankton diversity from different parts of India (Sharma, 1998; Khan, 2003; Kar, 2007; Sharma and Sharma, 2008). Some reports from Kashmir (Khan 1987), Bihar (Rai and Datta, 1988), West Bengal (Khan, 2002 and 2003; Ganesan and Khan, 2008), Assam (Sharma and Sharma, 2008; Kar and Barbhuiya, 2004) and Manipur (Sharma, 2009) are also available (Kar and Kar, 2016).

Present work was done to assess the diversity of zooplankton of Raja bandh pond of Jamtara district, Jharkhand. Present study was carried out keeping in view of above information and scarcity of literature from Jharkhand. Though few works on Zooplankton diversity was reported from Chaibasa, West Singhbhum (Sinha and Singh, 2016) and Bokaro (Saba and Sadhu, 2016) of Jharkhand but much more study is required from freshwater bodies of different parts of Jharkhand to establish a well-documented knowledge in area of zooplankton diversity from Jharkhand. Thus the present study was an attempt for reporting Zooplankton diversity of Raja Bandh Pond from Jamtara District of Jharkhand.

\section{Materials and Methods}

Raja bandh pond of new town is located at Jamtara district, Jharkhand. It lies between $23^{\circ} 95 \mathrm{~N}$ and $86^{\circ} 8^{\prime \prime} \mathrm{E}$. The artificial pond selected for the present study is small, open and shallow fresh water pond. The entire area is overwhelmingly rural with only small sacks of urbanization. The district is located at the lower altitude of Chhotanagpur plateau.

Zooplankton sampling was conducted for a period of one year from July 2018 to June 2019. Zooplankton were sampled weekly from the site following the standard methods of Battish (1992). Then the sample were filtered and placed in Tarson $(100 \mathrm{ml})$ container and fixed immediately in Lugol's solution and stored in cool and dark place. For studying the diversity of Zooplankton sample were taken in a Sedgwick-Rafter counting chamber and observed under a light microscope under prerequisite magnification ( $10 \mathrm{X}$ initially than followed by $40 \mathrm{X}$ ) and the specimens were identified following standard literature of Battish (1992); Edmondson (1959); Michael and Sharma (1998); Sharma (1998); Sharma and Sharma (2008).

\section{Results}

Present study revealed 14 genera of Zooplankton from the fresh water pond belonging to the four groups namely Rotifera, Cladocera, Copepoda and Ostracoda (Table 1). Among all four group maximum abundance of rotifers $(38 \%)$ were observed (Table 2$)$. Five species of rotifers, four species of cladocerans, three species of copepods and two species of ostracods were observed. The population density order observed as rotifers $>$ copepods $>$ cladocerans $>$ ostracods (Figure 1). 
Table 1: Abundance of Zooplankton species of Raja Bandh, New Town, Jamtara from July 2018 to June 2019

\begin{tabular}{|c|c|c|c|c|c|c|c|c|c|c|c|c|}
\hline $\begin{array}{l}\text { ZOO } \\
\text { PLANKTON }\end{array}$ & $\begin{array}{l}\text { JUL } \\
2018\end{array}$ & $\begin{array}{l}\text { AUG } \\
2018\end{array}$ & $\begin{array}{l}\text { SEP } \\
2018\end{array}$ & $\begin{array}{l}\text { OCT } \\
2018\end{array}$ & $\begin{array}{l}\text { NOV } \\
2018\end{array}$ & $\begin{array}{l}\text { DEC } \\
2018\end{array}$ & $\begin{array}{l}\text { JAN } \\
2019\end{array}$ & $\begin{array}{l}\text { FEB } \\
2019\end{array}$ & $\begin{array}{l}\text { MAR } \\
2019\end{array}$ & $\begin{array}{l}\text { APR } \\
2019\end{array}$ & $\begin{array}{l}\text { MAY } \\
2019\end{array}$ & $\begin{array}{l}\text { JUN } \\
2019\end{array}$ \\
\hline \multicolumn{13}{|l|}{ ROTIFERA } \\
\hline $\begin{array}{l}1 . \\
\text { Brachionus } \\
\text { sp. }\end{array}$ & 3 & 4 & 4 & 8 & 7 & 8 & 5 & 6 & 9 & 9 & 8 & 7 \\
\hline $\begin{array}{l}2 . \\
\text { Conochilus } \\
\text { sp. }\end{array}$ & - & - & - & - & - & - & - & 3 & 4 & 3 & 6 & 2 \\
\hline $\begin{array}{l}\text { 3. Polyarthra } \\
\text { sp. }\end{array}$ & 2 & 2 & 3 & 4 & 6 & 4 & 2 & - & - & 2 & 3 & 2 \\
\hline 4. Filinia sp. & 2 & 1 & 2 & 3 & 2 & 3 & 1 & 2 & 2 & 2 & 3 & 2 \\
\hline $\begin{array}{l}\text { 5. Plationus } \\
\text { sp. }\end{array}$ & - & - & - & - & 1 & 1 & 1 & 2 & 4 & 4 & 3 & - \\
\hline \multicolumn{13}{|l|}{ CLADOCERA } \\
\hline $\begin{array}{l}\text { 1. Daphnia } \\
\text { sp. }\end{array}$ & 3 & 3 & 3 & 4 & 4 & 1 & 1 & 2 & 1 & 5 & 6 & 7 \\
\hline $\begin{array}{ll}\text { 2. } & \text { Alonella } \\
\text { sp. } & \end{array}$ & 2 & 1 & 3 & - & - & - & - & - & 4 & 3 & 3 & 2 \\
\hline $\begin{array}{l}\text { 3.Diaphanos } \\
\text { oma sp. }\end{array}$ & 2 & 2 & 2 & 1 & 1 & - & - & 3 & 2 & 1 & 2 & 1 \\
\hline 4. Moina sp. & - & - & - & 1 & 1 & 1 & 1 & 1 & 2 & 4 & 3 & 2 \\
\hline \multicolumn{13}{|l|}{ COPEPODA } \\
\hline $\begin{array}{l}\text { 1. Cyclops } \\
\text { sp. }\end{array}$ & 1 & 1 & 4 & 2 & 2 & 2 & 1 & 5 & 5 & 7 & 9 & 8 \\
\hline $\begin{array}{l}\text { 2. Nauplius } \\
\text { sp. }\end{array}$ & 2 & 1 & 2 & 4 & 1 & 1 & 1 & 7 & 7 & 8 & 8 & 4 \\
\hline $\begin{array}{l}\text { 3. Heliodiapt } \\
\text { omus sp. }\end{array}$ & - & - & - & - & 1 & 1 & 2 & 1 & 5 & 5 & 6 & - \\
\hline \multicolumn{13}{|l|}{ OSTRACODA } \\
\hline 1.Cypris sp & 3 & 3 & 3 & 4 & 4 & 2 & 2 & 2 & 6 & 6 & 8 & 5 \\
\hline $\begin{array}{l}2 . \\
\text { Cyprinotus } \\
\text { sp. }\end{array}$ & - & - & 3 & 2 & 2 & 1 & 1 & 1 & 4 & 5 & 5 & - \\
\hline
\end{tabular}

Table 2: Monthly distribution of available Zooplankton density

\begin{tabular}{|l|c|c|c|c|c|}
\hline Months & ROTIFERA & CLADOCERA & COPEPODA & OSTRACODA & Total \\
\hline JUL 2018 & $\mathbf{7}$ & $\mathbf{7}$ & $\mathbf{3}$ & $\mathbf{3}$ & $\mathbf{2 0}$ \\
\hline AUG 2018 & $\mathbf{7}$ & $\mathbf{6}$ & $\mathbf{2}$ & $\mathbf{3}$ & $\mathbf{1 8}$ \\
\hline SEP 2018 & $\mathbf{9}$ & $\mathbf{8}$ & $\mathbf{6}$ & $\mathbf{6}$ & $\mathbf{2 9}$ \\
\hline OCT 2018 & $\mathbf{1 5}$ & $\mathbf{6}$ & $\mathbf{6}$ & $\mathbf{6}$ & $\mathbf{3 3}$ \\
\hline NOV 2018 & $\mathbf{1 6}$ & $\mathbf{5}$ & $\mathbf{4}$ & $\mathbf{6}$ & $\mathbf{3 1}$ \\
\hline DEC 2018 & $\mathbf{1 6}$ & $\mathbf{2}$ & $\mathbf{4}$ & $\mathbf{3}$ & $\mathbf{2 5}$ \\
\hline JAN 2019 & $\mathbf{9}$ & $\mathbf{2}$ & $\mathbf{4}$ & $\mathbf{3}$ & $\mathbf{1 8}$ \\
\hline FEB 2019 & $\mathbf{1 3}$ & $\mathbf{5}$ & $\mathbf{1 3}$ & $\mathbf{3}$ & $\mathbf{3 4}$ \\
\hline MAR 2019 & $\mathbf{1 9}$ & $\mathbf{9}$ & $\mathbf{1 7}$ & $\mathbf{1 0}$ & $\mathbf{5 5}$ \\
\hline APR 2019 & $\mathbf{2 0}$ & $\mathbf{1 3}$ & $\mathbf{2 0}$ & $\mathbf{1 1}$ & $\mathbf{6 4}$ \\
\hline MAY 2019 & $\mathbf{2 3}$ & $\mathbf{1 4}$ & $\mathbf{2 3}$ & $\mathbf{1 3}$ & $\mathbf{7 3}$ \\
\hline JUN 2019 & $\mathbf{1 3}$ & $\mathbf{1 2}$ & $\mathbf{1 2}$ & $\mathbf{5}$ & $\mathbf{4 2}$ \\
\hline Total & $\mathbf{1 6 7}$ & $\mathbf{8 9}$ & $\mathbf{1 1 4}$ & $\mathbf{7 2}$ & $\mathbf{4 4 2}$ \\
\hline Percentage & $\mathbf{3 7 . 7 0 = 3 8}$ & $\mathbf{2 0 . 3 2}$ & $\mathbf{2 5 . 7 9 = 2 6}$ & $\mathbf{1 6 . 2 9}$ & \\
\hline
\end{tabular}




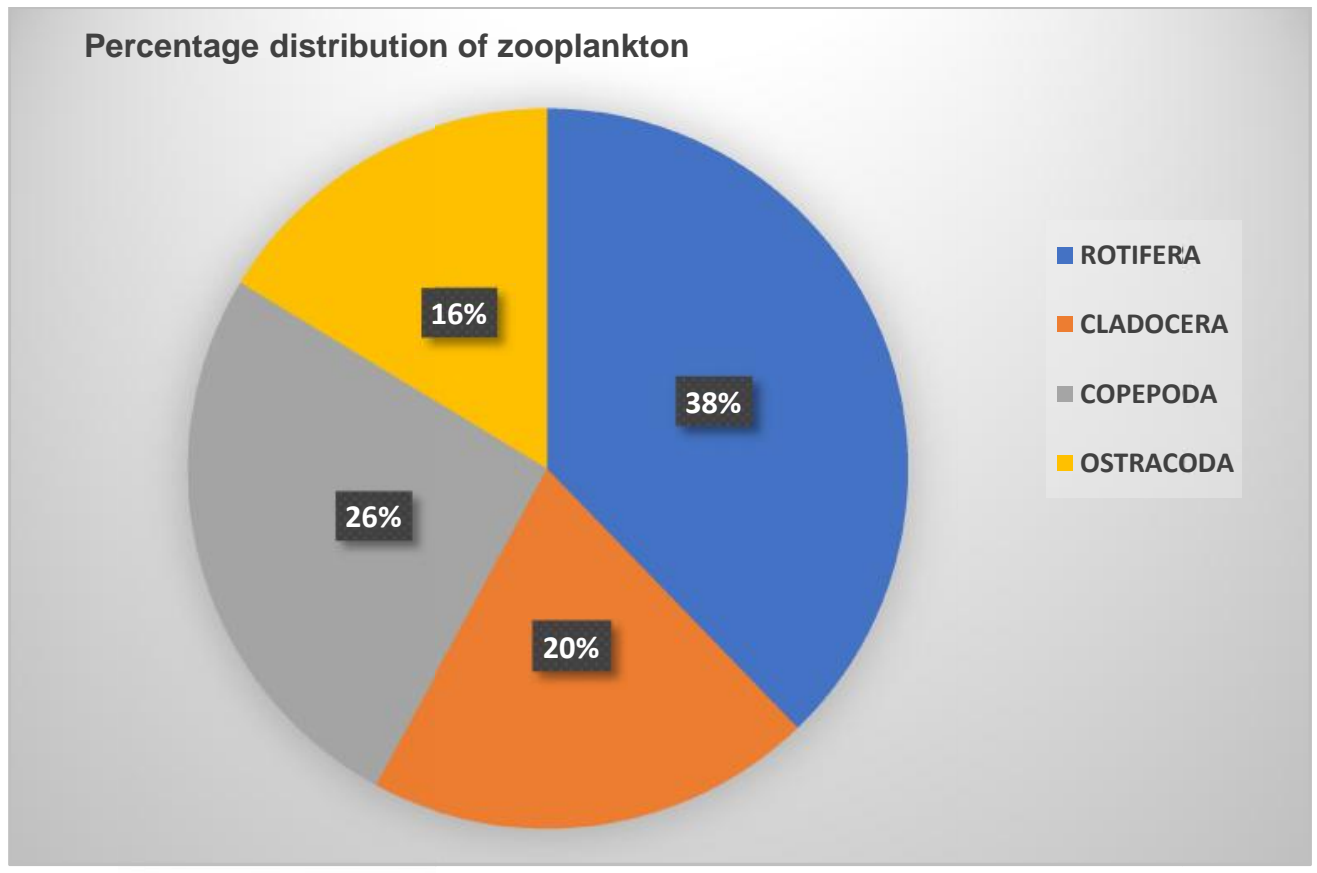

\section{Rotifera}

In the present study, the rotifers had a higher diversity in the summer months but a decreases in winters and rainy seasons. Among five species of rotifers, Brachionus $s p$, Plationus $s p$ and Filinia $s p$. were observed throughout the year but abundance of Conochilus $s p$ start to decreas during rainy season and even not observed in end of monsoon and winter. The abundance of Polyarthra $s p$ decreased during winter and rainy season but almost found throughout the year except February and March (Table 1).
The rotifera group Brachionus $\mathrm{sp}$ is an indicator of organic pollution was present throughout the year. Consequently the rotifers are globally documented as pollution indicator organisms in the aquatic environment. During the present study, Rotifera group was reported to be dominant among all other Zooplankton groups. In tropical freshwater wetlands, dominance of rotifera group is a common characteristic, similar was reported from the studies of Mwebaza-Nadwula, 2005. The present investigation revealed that the population density of Rotifera group reported from the study site vary in different seasons.

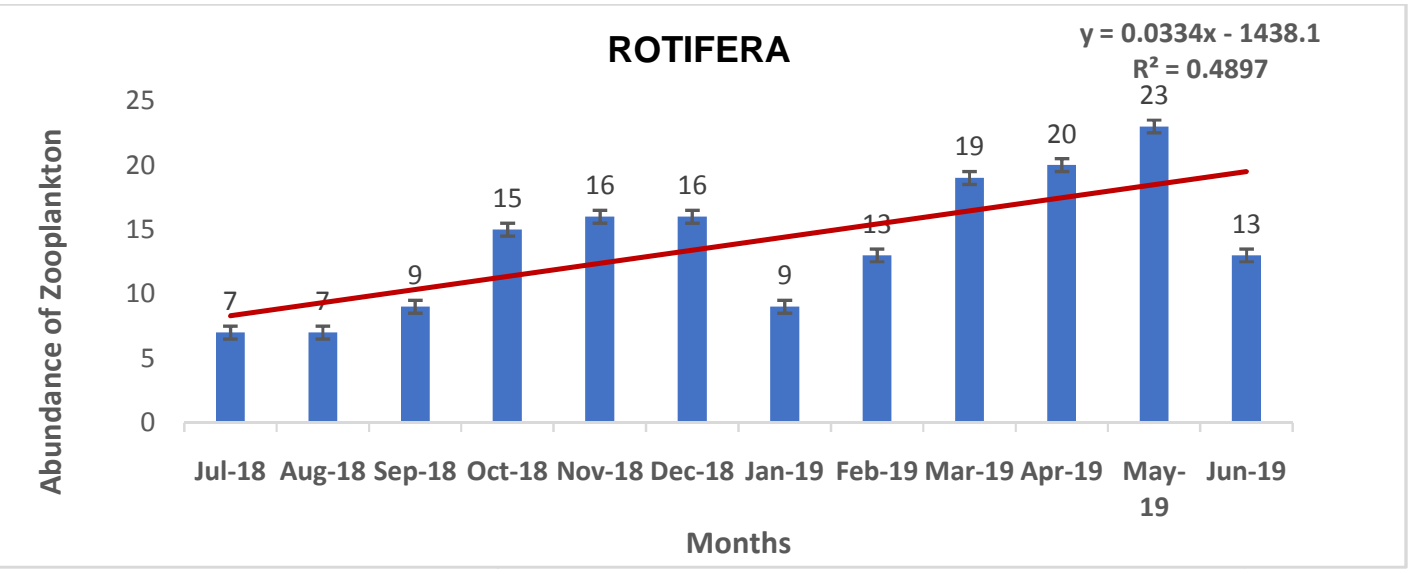

Figure 2: Study of Tree health with respect to altitude and distance from the settlement 


\section{Cladocera}

Four species of cladocerans namely Daphnia $s p$, Alonella Sp, Diaphanosoma sp, and Moina $s p$ were observed. Among all four species of cladocerans Daphnia $s p$ were observed throughout the year. The occurance of Diaphanosoma $s p$ found all the year except December and January during winter. The abundance of Alonella $s p$. were decreased during rainy days and not observed in winter while Moina sp population decreased in winter and not observed in rainy days. The data (Table 1) showed the diversity of cladocerans during different months of the year.

\section{Copepoda}

In the present study, the diversity of copepod during different months of the year was recorded (table 1). Three species of copepods namely Cyclops sp, Nauplius $s p$ and Heliodiaptomus $s p$ were observed. Among three species of copepods abundance of
Cyclops and Nauplius were observed throughout the year but Heliodiaptomus $s p$ population not observed during rainy season.

The maximum diversity of copepods was observed from February to June and dropped in winter from November to January (Table 1) and few specis not found during monsoon. Thus, copepod's positive correlation with temperature indicated their better development during warm period.

\section{Ostracoda}

Two species of ostracoda viz. cypris $s p$ and cyprinotus $s p$ were observed during this study. Present study revealed the occurance of cypris $s p$ throughout the year but cyprinotus was decreased in winter and not observed in rainy days. The population of ostracods was maximum in summer i.e. from march to June and decreased during winter from December to February.

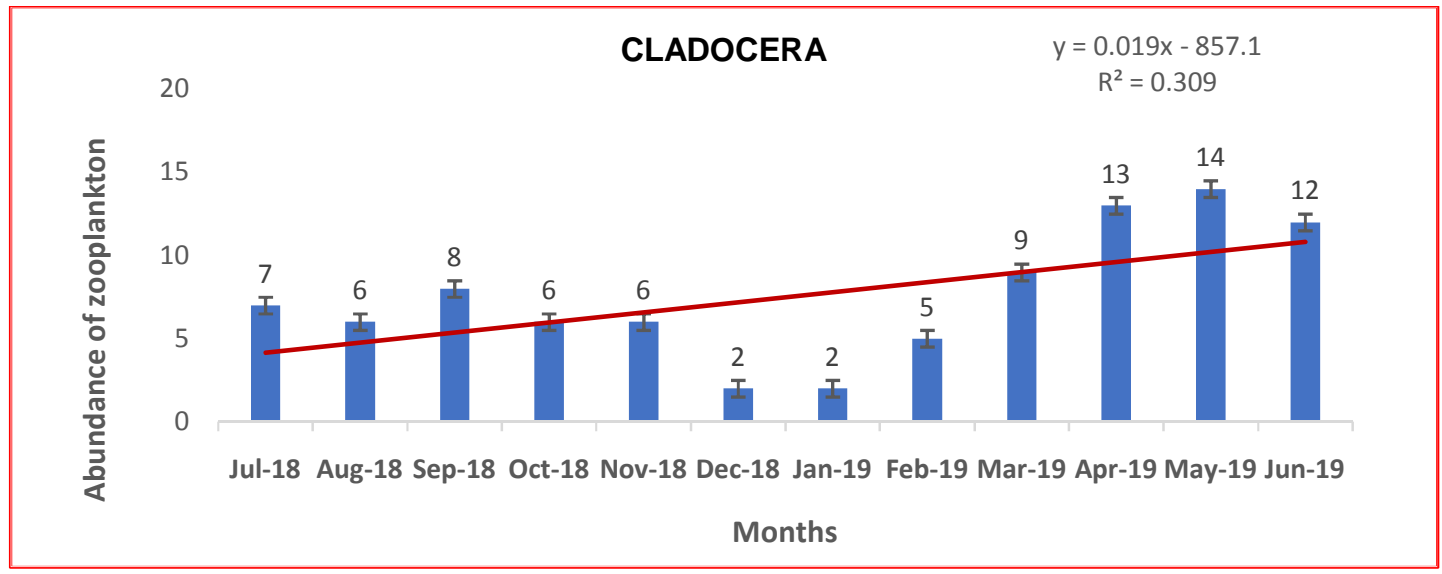

Figure 3 Monthly variation of cladocera throughout the year

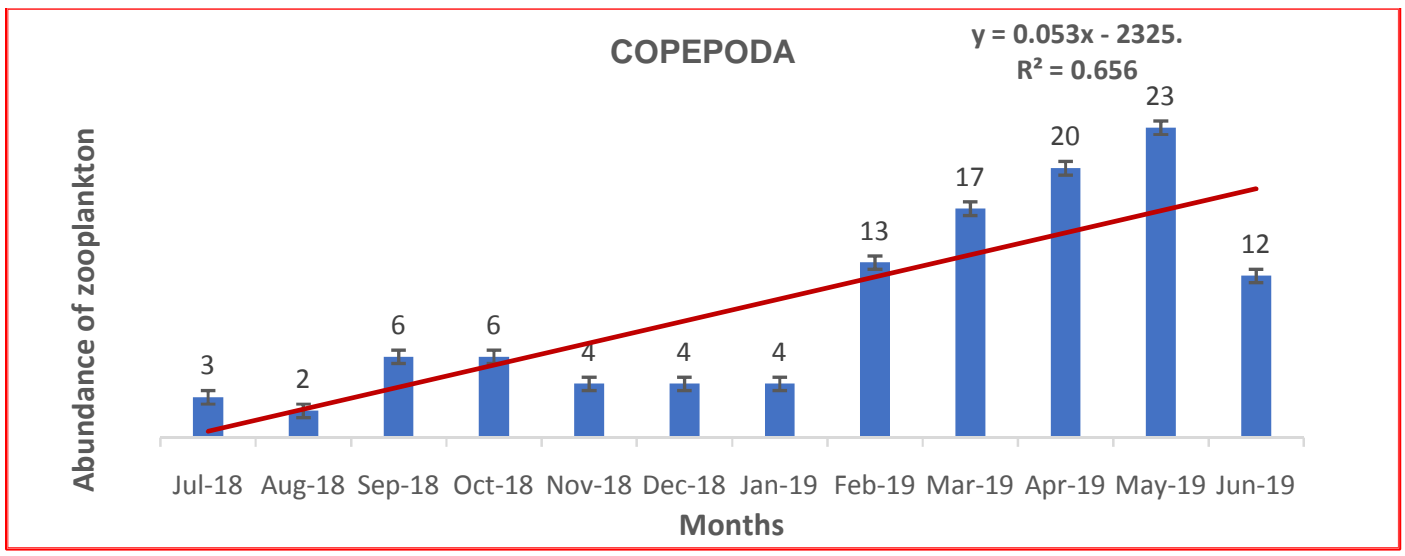

Figure 4: Monthly variation of copepods throughout the year 
Int J Adv Life Sci Res. Volume 4(2) 05-13

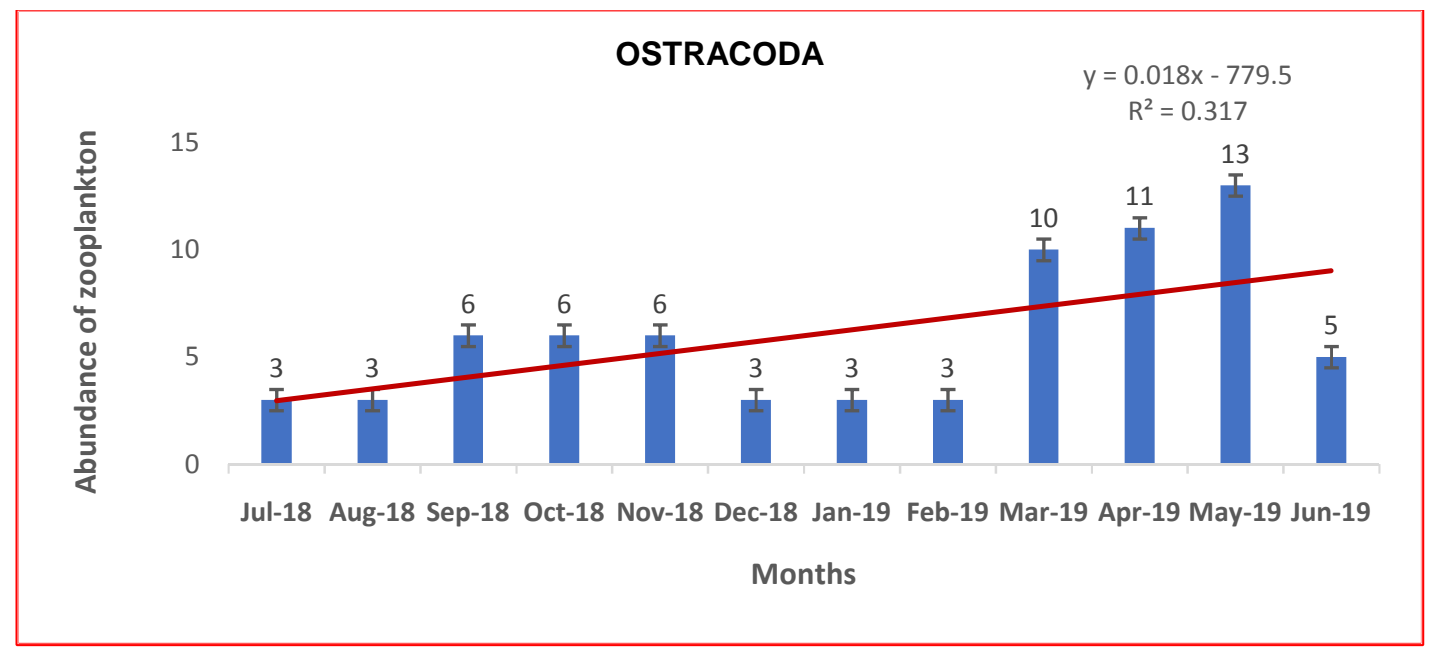

Figure 5: Monthly variation of ostracoda throughout the year

\section{Discussion}

Plankton have immense value as food and play an important role in disposal of sewage and natural purifiers of water. Zooplankton diversity is one of the most important ecological parameter in water quality assessment. Many workers has been done work on zooplankton diversity but very few reports available from Jharkhand. Hutchinson (1967) reported that the rotifera group Brachionus sp is an indicator of organic pollution and it is very common in temperate and tropical waters that showed the alkaline nature of water. Wilhm and Dorris (1968) reported that the rise in diversity of zooplankton were signal of the healthier environmental state while less diversity suggested fewer species dominance most likely due to sewage environmental pressure. Prabhavathy and Sreenivasan (1977) reported that copepods take much time to build up their population than rotifers and other zooplankton. However, once dominant, they continue to dominate the habitat. Marneffe et al. (1996) reported that the population of rotifers was high in summer and deprived in winter possibly due to high population of bacterial species and organic matter of dead and decaying vegetation. Rotifers respond very quickly to environmental changes than other planktonic species. The rotifers were dominant in municipal and industrial discharges while copepods and cladocerans were less abundant. Choubey (1997) observed the high density of copepod during October because the water temperature and availability of food to organisms which actually affected the copepod population during summer. Pullie and Khan (2003) reported that cladocerans mostly observed during winter season may be due to favourable temperature and availability of food, nanoplankton, suspended detritus. The physicochemical factors like DO, water temperature and turbidity also play crucial role in diversity and density of cladocerans. Bohra and Kumar (2004) however documented that the wetlands of Jharkhand, cladocerans were abundant from March to June and were either absent or present in very negligible numbers during the rest of months. Winkler (2002) reported the rise in atmospheric temperature caused enhancement in the evaporation rate and the positive correlation of copepods with temperature indicated their better development in warm periods after winter. Kamble and Meshram (2005) documented rotifers globally as pollution indicator organisms in the aquatic environment. Pandey et al, (2009) reported that decline in the number of cladocerans during rainy months may be due to race between cladocerans and other groups of zooplankton however the cladoceran richness was also reported higher in summer and minimum in winter. Das and Kar (2013) conducted their study to aim the zooplankton diversity including physico-chemical parameters. The study was carried out in Ramnagar annua (N 24049'57.3", E 92045'23.7") which is an oxbow-lake from September 2012 to August 2013 during 
different seasons. The physico-chemical parameters indicate the prevalence of good quality of water in the wetland. A total of 26 species of zooplankton were found from the study area. The species richness of the group rotifera (44.18\%) was highest. A total of 12 species belonging to 7 genera and 6 families were found during the period of investigation. These were followed by cladocerans, which were represented by 6 families comprising 9 species and 9 genera. There were 4 species of copepoda belonging to 2 families and 2 genera. The lowest diversity was exhibited by ostracods being represented by only species belonging to a single family. Majumder et al., (2014) reported that the Rotifers play an important role (as bio-indicator) to know the water quality of studied perennial water bodies. Saba and Sadhu (2015) reported zooplankton diversity of Garga Reservoir of Bokaro District Jharkhand. They reported the monthly variations and biodiversity indices of zooplanktons. They revealed 11 different species of zooplanktons belonging to 4 different classes namely 3 rotifers, 4 cladocerans, 3 copepods and 1 ostracod. Among rotifers, Brachionus falacatus is abundant. Ceriodaphnia cornuta is predominant among cladocerans. Among copepods, numerical superiority was found in case of Nauplius. Ostracoda was represented by only one genus i.e. Stenocypris. Manjare, (2015) studied zooplankton, of a particular water bodies such as Tamdalage, Laxmiwadi, Vadgaon tanks of Kolhapur district, Maharashtra. The water of the tank is used for domestic, Agriculture and fishery activities. The qualitative and quantitative study of zooplankton is carried out. Four major groups such as Rotifera, Cladocera, Copepoda and Ostracoda were identified. Among these group 27 species from 3 orders and 2 families were identified and recorded from Tamdalge, Laxmiwadi and Vadgaon tanks. Among Copepoda 10 species belonging to order Eucopepoda were identified and recorded. These are Mesocyclops hyalinus, Paracyclops strigilipes, Neodiaptomus fimbriatus, Rhinedioptomus indicus, Diaptomus copepod, Calanoid copepods Eucyclopoid species, Cyclopoid copepod, whereas Cladocerans are represented by Monia macrocopa, $M$. rectirostrix, M. brachiatatris, Daphnia pulex, Euryalona oriantalis, Diaphanosoma sarsi, $D$. excisum, Macrothrix laticornis. The Ostracodas are represented by Spirocypris, Hyocypris gibba, Hemicypris fossulate, Stenocypris from the plankton samples of these tanks.The Rotifera species like Brachionus angularis, B. cadatus, B. falcatus, $B$. calyciflorus, B. vulgaris were observed as common forms throughout the investigation period while $B$. rubens and Keratella tropica were recorded infrequently in the plankton samples of these tanks. Monthly variations in percent composition of zooplankton at Tamdalge, Laxmiwadi and Vadgaon tanks are recorded. Singh and Singh, (2016) reported presence of 29 zooplankton species on the basis of one year data of jubilee pond, Chaibasa, West Singhbhum, Jharkhand. They reported that during winter Cladocerans were the most dominant group followed by Copepoda. On the other hand, rotifers and Cladocerans were the most dominant during summer. Certain species e.g. Brachionus calyciflorus, Brachionus falcatus, Monostyla quadridentatus, Trichotria sp., Cyclops sp., Cypris sp., and Daphnia carinata were recorded throughout the year. Das and Kar, (2016) again studied the diversity of various types of zooplankton and the result revealed that the zooplankton was represented by various genera viz., cladocera, rotifera, copepoda and ostracoda. The numbers of varieties of group rotifera have been reported maximum but the percentage amount of cladocera group followed by rotifera in general. The annual percentage composition of various representative groups revealed $38.84 \%$ cladocera, $37.13 \%$ rotifera, $23.56 \%$ copepoda and $0.46 \%$ ostracoda. The detailed aspect of seasonal variation, percentage composition and diversity of zooplankton is discussed herein. Kar and Kar, (2016) reported that zooplankton are cosmopolitan in nature and they are found to inhabit all freshwater tropical wetlands. They studied monthly changes of diversity and density of zooplankton in Sat beel of Cachar, Assam. The work was carried out for a period of one year from September 2014 to August 2015. The population status of Zooplankton at Sat beel consisted of 40 genera, categorized into 
three major groups, viz, Rotifera $>$ Cladocera $>$ Copepoda. The Zooplankton sample consisted of $53 \%$ Rotifera, $25 \%$ Cladocera and $22 \%$ Copepoda respectively. Rotifera were the dominant group of Zooplankton recorded with respect to diversity and population density status.

Kaur et al., (2018) studied zooplankton diversity in the polluted water stretch of Buddha Nullah, Ludhiana. They identified two phyla such as Rotifer and Crustacean. Among rotifer 3 species and among crustacea 4 species of cladocera and 4 species of copepod were identified. The dominant zooplankton were present throughout the year. The seasonal zooplankton diversity showed that the pollution indicator Brachionus sp. of rotifera were found at polluted water spots i.e. Jamalpur, Sunder Nagar and Walipur (downstream) during summer months and crustaceans (both copepods and cladocerans) recorded in both summer and winter seasons at non-polluted spots i.e. Machhiwara and Buddhewal (upstream). The pollution indicator species of rotifers at downstream spots describes the higher levels of organic pollution and eutrophication of Buddha Nullah. The pollution of Buddha Nullah emphasizes the fact that water is unfit for consumption and domestic use. The effect of water on human and domestic animals would also be harmful to health. Kaur et al., (2018) also reported that the temperature was most important factor that affects the copepods density and diversity. Their production increased with increase in temperature. This may be due to the fact that the higher temperature increased the biochemical \& biological activities and increased the production of microorganisms.

\section{References}

Alam AKMN, Islam MA, Mollah MFA and Haque M $S$ (1987). Status of zooplankton in newly constructed ponds and their relation to some meteorological and limnological factors. Bangladesh Journal of Fisheries, 14(1): 83-88.

Battish, S.K. (1992). Freshwater zooplankton of India. Oxford and IBH Publishing Co., New Delhi. 233.

Bohra S, Kumar K (2004), Plankton diversity in the wetlands of Jharkhand. In: Kumar A (ed))

\section{Conclusion}

Zooplankton diversity in water of raja band showed that mainly four group's viz., Rotifera, cladocera, copepoda and ostracoda. Among rotifers, Brachionus sp, Plationus sp, Filinia, Conochilus $s p$ and Polyarthra $\mathrm{sp}$ were recorded. Among cladocerans Daphnia $s p$, Alonella Sp, Diaphanosoma sp, and Moina sp and in copepods Cyclops sp, Nauplius $s p$ and Heliodiaptomus $s p$ and were found. Only two species of ostracoda were observed namely cypris $s p$ and cyprinotus $s p$. The objective of this investigation was to know the zooplankton diversity in a fresh water pond (raja bandh) of jamtara, jharkhand and to develop our knowledge about the fact that the biodiversity of a fresh water pond is endowed with a great harbor of different fauna, especially the zooplankton as they are playing a vital role in the stability and integrity of aquatic ecosystem. This study revealed diversity of zooplankton in one pond so for develop much stronger information advance study is needed for any scientific utilization. Also a depth information and knowledge is needed to analyze its community and dynamics.

\section{Acknowledgments}

The authors are thankful to Deoghar College, Deoghar, Department of Zoology, Sido Kanhu Murmu University, India.

\section{Conflicts of Interest}

The authors declare that there are no conflicts of interest.

Biodiversity Environ. APH Publishing Corporation, New Delhi (India), 91122.

Choubey U (1997) Population dynamics of copepods in relation to water quality of jannapura Tank. J Aqua Biol. 21(2):67-71.

Contreras JJ, Sarma SSS, Merino-lbarra M and Nandini S (2009) Seasonal changes in the rotifer (Rotifera) diversity from a tropical high altitude reservoir (Valle de Bravo, Mexico). Journal of Environmental Biology. 30:191-195. 
Edmondson, W.T. (1959). Freshwater Biology 2nd Ed. John Wiley and Sons Inc., New York: 1-1248.

Ganesan L and Khan RA (2008) Studies on Ecology of Zooplankton in a Floodplain Wetland of West Bengal, India. In Sengupta, M. and R. Dalwani (Eds) Proceedings of Taal2007: The 12th World lake Conference: 67-73.

Hutchinson GE (1967) A treatise on Limnology, Vol. II: Limnoplankton. Wiley New York, 1015.

Kamble BB, Meshram CB (2005) A preliminary study on Zooplankton diversity at Khatijapur tank, near Achlapur, District Amravati, Maharastra. J Aqua Biol. 20(2):45-47.

Kar S and Kar D (2016) International Journal of Applied Biology and Pharmaceutical Technology International Journal of Applied Biology and Pharmaceutical Technology.7 (1). 301-305.

Kar D and Barbhuiya MH (2004) Abundance and diversity of zooplankton in Chatla Haor, a floodplain wetland in Cachar district of Assam. Environment and Ecology, 247-248.

Kar D (2007) Fundamentals of Limnology and Aquaculture Biotechnology. Daya Publishing House, $x i v+609$

Kar S and Kar D (2013) Studies on zooplankton diversity of an oxbow lake of South Assam, India. International Journal of Current Research, 5(12):3652-3655

Kar, D. (2013). Wetlands and Lakes of the World. Springer, London.

Kaur A, Hundal SS and Aulakh RK (2018) Seasonal study of zooplankton diversity in the polluted water stretch of Buddha Nullah, Ludhiana. Journal of Entomology and Zoology Studies 2018; 6(5): 2241 2245.

Khan MA (1987) Observations on zooplankton composition, abundance and periodicity in two floodplain lakes of Kashmir Himalayan valley. Actahydrochem. Hydrobiol, 15: 176-174

Khan RA (2002) The ecological and faunal diversity of two ox-bowlakes of southeastern West Bengal. Record Zoological Survey of India. Occasional Paper. No. 194:1104.

Khan RA (2003) Faunal diversity of zooplankton in freshwater wetlands of south-eastern West Bengal. Record Zoological Survey of India. Occasional Paper. No. 204:1107

Manjare SA (2015) Qualitative and quantitative study of zooplankton from fresh water tanks of kolhapur district, (maharashtra). Research Journal of Life sciences, Bioinformatics, Pharmaceuticals and Chemical Sciences 1(1) 54-58.
Marneffe Y, Descy JP, Thome JP (1996) The zooplankton of the lower river Meuse, Belgium: seasonal changes impact of industrial and municipal discharges. Hydrobiol. 319:1-13

Miah MF, Roy S, Jinnat E and Khan Z K (2013) Assessment of Daphnia, Moina and Cylops in Freshwater Ecosystems and the Evaluation of Mixed Culture in Laboratory. American International Journal of Research in Formal, Applied \& Natural Sciences, 4(1): 1-7.

Mwebaza-Nadwula, M, Sekiranda L, and Kiggundu V. (2005) Variability in zooplankton community along a section of the Upper Victoria Nile, Uganda. Afr. J. Ecol., 43: 251-257.

Pandey BN, Ambasta OP, Thakur AK, Kumar S, Kumari R (2009) Zooplankton diversity in relation to certain physicochemical parameters of swamp of Kishanganj, Bihar. Environ Conserv J. 10(1, 2):914.

Prabhavathy G, Sreenivasan A (1977). Ecology of warm freshwater zooplankton of Tamil Nadu. Proc Sym warm water zooplankton, N.I.O., Goa. 319-99.

Pullie JS, Khan AM (2003). Studies on zooplankton community of Isapur dam water. Ind Poll Res. 22:451-455.

Rai DN and Dutta Munshi (1988) Ecological characteristics of chaurs of North Bihar. WetlandsEcology and Management.2: 88-95.

Saba F and Sadhu DN (2015) Zooplankton Diversity of Garga Reservoir of Bokaro, Jharkhand, India Int. J. Bioassays. 4 (04), 3792-3795

Sharma BK (1998) Freshwater Rotifers (Rotifera: Eurotatoria). Fauna of West Bengal. State Fauna Series, 3(11): 341-461

Sharma BK (2009) Diversity of Rotifers (Rotifera: Eurotatoria) of Loktak lake, north-eastern India. Tropical Ecology. 50: 277-285

Sharma BK and Sharma S (2008) Zooplankton diversity in floodplain lakes of Assam. Records of Zoological Survey of India. Occasional paper no 290: 1-307.

Steinberg D K and Robert H (2009). Zooplankton of the York River. Journal of Coastal Research. 57: 66-79

Wilhm JL and Dorris TC (1968) Biological parameters for water quality criteria. Bioscience. 1968; 18(6):477-81.

Winkler HM (2002). Effects of eutrophication on fish stocks in Baltic lagoons. In Baltic Coastal Ecosystems (Eds. G. Schernewski and U. Schiewer), Springer-Verlag, Berlin. 65-74. 